\title{
The Effect of Bleaching Agents on Human Enamel Microhardness
}

\author{
Tatjana Savić-Stanković, Branislav Karadžić \\ Department of Restorative Dentistry and Endodontics, School of Dentistry, University of Belgrade, Belgrade, Serbia
}

\begin{abstract}
SUMMARY
Introduction Bleaching agents can cause alteration of hard tissues of the tooth. The aim of this study was to evaluate the effect of two different concentrations of carbamide peroxide ( $10 \%$ and $35 \%$ ) on human enamel microhardness.

Material and Methods The study was conducted on ten extracted teeth divided into two groups. The teeth were sectioned in mesiodistal direction using the diamond disc in order to obtain experimental and control samples. First group was exposed to the concentration of $10 \%$ carbamide peroxide (Opalescence gel, Ultradent. Pro, US) at the time intervals that corresponded to home night bleaching technique of vital teeth. Second group was exposed to high concentration of $35 \%$ carbamide peroxide (Opalescence Quick, Ultradent. Pro, US) at the time intervals that corresponded to the professional bleaching technique of vital teeth. Control samples were exposed to artificial saliva for the same time intervals as the samples from experimental group. Knoop's test for enamel microhardness was performed at the beginning, after the first phase of therapy, after the therapy was completed and after three weeks of exposure to artificial saliva. The results were statistically analyzed using analysis of variance (ANOVA) and Student t-test.

Results The microhardness values of enamel samples treated with 10\% carbamide peroxide decreased after 8 hours ( $261 \mathrm{khn})$ and three weeks of treatment $(222 \mathrm{khn}$ ) but increased after three weeks of exposure to artificial saliva (263 khn). The decrease of enamel microhardness of the samples treated with $10 \%$ carbamide peroxide was not statistically significant. The microhardness values of enamel samples treated with $35 \%$ carbamide peroxide were reduced after 1 hour (235 khn) and 3 hours (190 khn) and increased after three weeks of exposure to artificial saliva (241 khn). Microhardness of enamel treated with $35 \%$ carbamide peroxide was significantly decreased in experimental samples compared to controls.
\end{abstract}

Conclusion Carbamide peroxide in concentration of $35 \%$ leads to the significant decrease in enamel microhardness compared to $10 \%$ carbamide peroxide.

Keywords: urea peroxide; teeth bleaching; enamel microhardness

\section{INTRODUCTION}

For a long time, white teeth have been considered as an indicator of health as well as an important factor of youth and beauty. Looking for the conservative, the least aggressive and economically acceptable treatment, bleaching teeth has become an important part of dental practice. The first publication regarding vital teeth bleaching techniques by Haywood and Heymann [1] in 1989 has introduced a new approach in bleaching teeth. Nowadays, the most frequently used bleaching agents are based on hydrogen peroxide or carbamide peroxide. Carbamide peroxide in concentration of $10-22 \%$ is the major agent for bleaching vital teeth by home night technique, while the concentration of $35 \%$ is used for professional bleaching of vital teeth in dental office. Carbamide peroxide in situ decomposes into urea, ammonia, carbon dioxide, water and hydrogen peroxide where the latter is the active bleaching substance [2].

Bleaching agents have effect on chemical / physical and morphological structure of enamel that must be taken into account when this therapy is used. Several studies have shown correlation between changes on the surface of enamel (microhardness, structural changes) and the concentration of bleaching agent $[3,4]$.

Past research concerning the effect of carbamide peroxide on dental enamel during teeth bleaching has shown significant contradictions [5-8]. Some studies claim that changes in enamel structure are minor and return to the original level after bleaching is completed while others declare the opposite. Ferreira et al. [9] found that contact between bleaching gel ( $\mathrm{pH}$ 5.5) and enamel in a short period of time (not longer than 30 minutes) does not lead to changes in enamel microhardness. On the contrary, the studies of Rotstein et al. [4], Leonard et al. [10], Attin et al. [11] and many others reported a significant reduction in microhardness of enamel even after the period of remineralization. Recent study of Basting et al. [12] showed a significant decrease in microhardness of enamel after application of $10 \%$ carbamide peroxide for 8 hours per day during 42 days. The value of microhardness returned to the initial level after remineralization period of 7 days. Research done by Araujo et al. [13] indicated significant reduction of enamel microhardness after application of 
$10 \%$ carbamide peroxide for 1 hour or 7 hours per day during three weeks in both cases. Smidt et al. found lesser reduction of enamel microhardness after exposure to $10 \%$ carbamide peroxide gels ( 6 hours per day during 16 days) with a $\mathrm{pH}$ range from 4.3 to 5.5 [14].

The effect of bleaching products based on high concentrations of carbamide peroxide (35\%) and hydrogen peroxide (30 to 38\%) used in dental office ("power" bleaching) on biomechanical characteristics of enamel was also evaluated. These concentrations are normally used either as a separate technique or in combination with at home night bleaching technique. Carbamide peroxide in the concentration of $35 \%$ is the highest concentration available at the market and it corresponds to $11.4 \%$ of hydrogen peroxide solution. The research performed by Sulieman et al. [15] did not observe a significant change in microhardness of enamel after application of 35\% carbamide peroxide for 30 minutes. The studies done by Attin et al. [11] and Lewinstein et al. [16] indicated a significant reduction of enamel microhardness after the treatment with $35 \%$ of hydrogen peroxide or 35\% of carbamide peroxide fully recovered after the application of $0.05 \%$ fluoride solution. Numerous studies reported different levels of enamel microhardness reduction after application of $35 \%$ carbamide peroxide [3, 17-20].

The aim of this study was to examine the effect of carbamide peroxide products in two different concentrations on enamel microhardness.

\section{MATERIAL AND METHODS}

Ten intact, noncarious premolars and third molars extracted for orthodontic indications were used in the study. The teeth were divided into two groups of 5 teeth. After extraction, the teeth of both groups were immersed in distilled and deionized water at $37^{\circ} \mathrm{C}$ in order to prevent dehydration. The teeth were cleaned in an ultrasonic bath 3 times for 15 minutes. Prior to experiment the teeth were stored in artificial saliva in a water bath at the temperature of $37^{\circ} \mathrm{C}$ for 24 hours. Using a low speed diamond disc the root was cut 2-3 $\mathrm{mm}$ from the enamel-cement junction in apical direction. The teeth were sectioned in mesiodistal direction using a diamond disc (Brasseler Gebr. \& COMET, Germany) at low speed giving the two halves, one was experimental and one was control sample. Each half was embedded into autopolymerizing acrylate (Simgal-R, Galenika) using a cylindrical plastic mold with the diameter of $3 \mathrm{~cm}$. The vestibular side (the enamel) was exposed. Outer surface of enamel was flattened using water-cooling discs (Minnesota Mining \& MFG.Co.3M) of 180, 320 and 600 micron fineness. This procedure provided the parallel area of about $9 \mathrm{~mm}^{2}$ to measure microhardness by Knoop's test. For the teeth halves from the first group which were subjected to $10 \%$ carbamide peroxide, ten individual trays were made before the treatment in order to simulate the situation in the mouth. A tray was made of flexible ethyl vinyl acetate polymer having $0.9 \mathrm{~mm}$ thickness (Soft-Tray, Ultradent Product. Inc). For each tooth the tray was made separately using a Vacuum former (Ultradent. Pro, US).
Experimental halves from the first group were subjected to $10 \%$ carbamide peroxide solution ( $\mathrm{pH}$ 6.5) (Opalescence gel, Ultradent. Pro, US) for the time intervals that corresponded to the clinical application of homenight vital teeth bleaching technique (manufacturers recommendation). Their corresponding control halves were exposed to the artificial saliva for the same time intervals. All samples were immersed in tested bleaching agent and artificial saliva (experimental and control) for 8 hours during three weeks. Each half was covered with the tray and placed in a covered container containing artificial saliva $(\mathrm{pH} 7.0)$ at $37^{\circ} \mathrm{C}$. After 8 hours, the halves were removed and rinsed with distilled unionized water for 5 seconds. During the remaining 16 hours (during the day), the fragments were immersed in separate closed containers with artificial saliva ( $\mathrm{pH} 7.0)$ at $37^{\circ} \mathrm{C}$. Artificial saliva in the containers was changed every third day. After completion of the treatment (21 days), experimental and control halves were stored in artificial saliva only, for three weeks. Knoop's microhardness test for experimental and control halves was done at the beginning of the experiment, after 8 hours, after three weeks of the treatment (21 days) and after three weeks of storage in artificial saliva, respectively.

Experimental halves from the second group were treated with 35\% carbamide peroxide ( $\mathrm{pH}$ 6.0) (Opalescence Quick, Ultradent. Pro, US) at intervals corresponding to the clinical application for vital teeth bleaching method in dental office while the control halves were subjected to artificial saliva for the same time intervals. The teeth halves were exposed to the tested bleaching agent and artificial saliva (experimental and control) for 60 minutes every second day (three times a week). For the remaining time, they were stored in containers with artificial saliva $(\mathrm{pH} 7.0)$ at $37^{\circ} \mathrm{C}$. Knoop's microhardness test was evaluated at the beginning, after 60 minutes of the treatment, following the series of three times of 60 minutes (at the end of the treatment) and after three weeks of storage in artificial saliva.

Three measurements in the middle third of the crown with a load of 50 grams during 30 seconds were performed for all samples from the first and the second group using the device Leitz Wetzlar 7569 (Germany). Statistical analysis was done using the analysis of variance (ANOVA) and Student t-test for independent samples.

\section{RESULTS}

The mean value of microhardness for the experimental samples exposed to $10 \%$ carbamide peroxide at the beginning of measurements was $273.08 \mathrm{khn}$, after $8 \mathrm{~h}$ of exposure $261.06 \mathrm{khn}$, after three weeks of the treatment microhardness decreased to $222.15 \mathrm{khn}$. After the period of three weeks of exposure to artificial saliva, microhardness of enamel increased to $262.53 \mathrm{khn}$ (Table 1). Changes in microhardness for the experimental samples were not statistically significant $(\mathrm{F}=0.670 ; \mathrm{p}>0.05)$.

The average values of microhardness for the control samples were fairly consistent during the experiment. The difference in microhardness values between the experi- 
Table 1. The average values of microhardness of experimental (E) and control (C) samples exposed to 10\% carbamide peroxide

Tabela 1. Srednje vrednosti mikrotvrdoće eksperimentalnih (E) i kontrolnih (K) uzoraka izlaganih karbamid-peroksidu u koncentraciji od 10\%

\begin{tabular}{|c|c|c|c|c|c|c|c|c|}
\hline \multirow{2}{*}{$\begin{array}{l}\text { Value } \\
\text { Vrednost }\end{array}$} & \multicolumn{2}{|c|}{$\begin{array}{l}\text { Beginning } \\
\text { Početak }\end{array}$} & \multicolumn{2}{|c|}{$\begin{array}{l}\text { After } 8 \text { hours of therapy } \\
\text { Posle osam sati terapije }\end{array}$} & \multicolumn{2}{|c|}{$\begin{array}{l}\text { After three weeks of therapy } \\
\text { Posle tri nedelje terapije }\end{array}$} & \multicolumn{2}{|c|}{$\begin{array}{l}\text { Remineralization } \\
\text { Remineralizacija }\end{array}$} \\
\hline & $E$ & $\mathrm{C} / \mathrm{K}$ & E & $\mathrm{C} / \mathrm{K}$ & $E$ & $\mathrm{C} / \mathrm{K}$ & $E$ & $\mathrm{C} / \mathrm{K}$ \\
\hline $\bar{x}$ & 273.08 & 285.34 & 261.06 & 280.85 & 222.15 & 282.87 & 262.53 & 281.88 \\
\hline SE & 33.56 & 25.07 & 30.46 & 24.69 & 18.97 & 24.31 & 23.84 & 22.80 \\
\hline SD & 75.04 & 56.07 & 68.12 & 55.20 & 42.41 & 54.35 & 53.30 & 50.99 \\
\hline $\begin{array}{l}\text { Variance } \\
\text { Varijansa }\end{array}$ & 5631.35 & 3143.54 & 4640.31 & 3047.54 & 1798.63 & 2953.73 & 2841.06 & 2599.52 \\
\hline
\end{tabular}

ANOVA: $F=0.660 ; p>0.05$

$\bar{X}$ - average value; SE - standard error; SD - standard deviation

$\bar{X}$ - srednja vrednost; SE - standardna greška; SD - standardna devijacija

Table 2. The average values of mic rohardness of experimental (E) and control (C) samples exposed to $35 \%$ carbamide peroxide Tabela 2. Srednje vrednosti mikrotvrdoće eksperimentalnih (E) i kontrolnih (K) uzoraka izlaganih karbamid-peroksidu u koncentraciji od 35\%

\begin{tabular}{|c|c|c|c|c|c|c|c|c|}
\hline \multirow[t]{2}{*}{$\begin{array}{l}\text { Value } \\
\text { Vrednost }\end{array}$} & \multicolumn{2}{|c|}{$\begin{array}{l}\text { Beginning } \\
\text { Početak }\end{array}$} & \multicolumn{2}{|c|}{$\begin{array}{l}\text { After } 1 \text { hour of therapy } \\
\text { Posle jednog sata terapije }\end{array}$} & \multicolumn{2}{|c|}{$\begin{array}{l}\text { After } 3 \text { times per } \\
60 \text { minutes of therapy } \\
\text { Posle tri puta po } \\
60 \text { minuta terapije }\end{array}$} & \multicolumn{2}{|c|}{$\begin{array}{l}\text { Remineralization } \\
\text { Remineralizacija }\end{array}$} \\
\hline & $\mathbf{E}$ & $\mathrm{C} / \mathrm{K}$ & $\mathbf{E}$ & $\mathrm{C} / \mathrm{K}$ & $\mathbf{E}$ & $\mathrm{C} / \mathrm{K}$ & E & $\mathrm{C} / \mathrm{K}$ \\
\hline $\bar{x}$ & 261.00 & 262.60 & 234.60 & 261.80 & 190.00 & 262.60 & 241.20 & 260.80 \\
\hline SE & 6.00 & 10.47 & 6.90 & 8.62 & 5.83 & 10.47 & 4.00 & 9.83 \\
\hline SD & 13.42 & 23.41 & 15.42 & 19.28 & 13.04 & 23.41 & 8.96 & 21.98 \\
\hline $\begin{array}{l}\text { Variance } \\
\text { Varijansa }\end{array}$ & 180.00 & 547.80 & 237.80 & 371.70 & 170.00 & 547.80 & 80.20 & 483.20 \\
\hline
\end{tabular}

$t=5.139 ; p<0.05$

ANOVA (E:C/K): $F=4.434 ; p<0.05$

mental and the control samples was not statistically significant $(\mathrm{F}=0.660 ; \mathrm{p}>0.05)$

The mean value of microhardness for the experimental samples exposed to $35 \%$ carbamide peroxide at the beginning of the experiment was $261.00 \mathrm{khn}$, after 1 hour of exposure to the bleaching gel decreased to $234.60 \mathrm{khn}$ while after three hours it was $190.00 \mathrm{khn}$. After three weeks of storage in the artificial saliva, microhardness of the samples increased to $241.20 \mathrm{khn}$ (Table 2). The greatest difference in microhardness values was found between the initial values and the values of microhardness after 3 hours of the treatment $(\mathrm{t}=5.139 ; \mathrm{p}<0.05)$.

The average values of microhardness for the control samples were approximately the same during the experiment. The difference in microhardness of the experimental and the control samples after the treatment using 35\% carbamide peroxide was statistically significant $(\mathrm{F}=4.434$; $\mathrm{p}<0.05)$.

The difference in the microhardness of the experimental and the control samples after a period of remineralization was not statistically significant.

\section{DISCUSSION}

Hardness of solid substances can be determined by static, dynamic and special methods. Static methods by Knoop and Vickers are used to measure microhardness of hard dental tissues. The force exerted on a test indenter gradually increases to the maximum value [21]. Knoop's test for microhardness has been adopted as one of the main experimental methods for the analysis of changes in enamel and dentin physical properties after exposure to various agents. That was the reason for its use in current study $[3,5,6]$.
The most valid results for the detection of enamel physical properties alteration caused by different bleaching agents can be obtained from in vivo research. Buffering potential of saliva can not be ignored as well as its specific remineralization effect. The composition of saliva is variable during the day making difficult to simulate physiological conditions in the experimental setup [11].

During the process of bleaching, hydrogen peroxide diffuses through the organic matrix of enamel. Hydrogen peroxide is oxidative agent and has ability to produce highly reactive peroxide and superoxide ions. Although bleaching is a complex process, the main reaction is oxidation [22]. Molecular changes occur within the organic matter of hard tissues [4]. As a result of oxidation of the enamel organic and inorganic substance, the enamel matrix is dissolved and various side effects come out. The side effects appear as decrease in enamel microhardness and change of enamel morphological characteristics [23]. The effect of bleaching is directly dependent on exposure time and concentration of bleaching agent. Longer the period of exposure and the concentration of bleaching agent, a color change will be more pronounced. However, longer the oxidation process causes greater effects on hard tissue $[19,20,21]$. The impact of bleaching agents on possible side effects depends also on $\mathrm{pH}$ of the agent as well as on the quality of dental hard tissues [24].

The current study found changes in microhardness of the treated enamel surface after application of carbamide peroxide in higher concentrations. Observed difference in enamel microhardness values is most probably result of different concentrations of bleaching agents and exposure times. The load (force), the diameter of diamond indenter and the indentation time were strictly controlled and standardized. In addition, bleaching agents used in this study 
had $\mathrm{pH}$ values above the critical for the demineralization of enamel. The results of this study also showed that there was no statistically significant reduction of microhardness after treatment with $10 \%$ carbamide peroxide. This can be explained by the fact that it is very low concentration of carbamide peroxide which breaks down onto 7\% urea and $3 \%$ hydrogen peroxide after contact with the saliva and oral fluid. Hydrogen peroxide further breaks onto water and nascent free oxygen [1]. After keeping samples in artificial saliva, there was an increase in microhardness which can be associated to remineralization effect of saliva [25].

Results of the current study are consistent to the results of Murchison, Nathoo, Seghi, Unlu et al. [5-8], who reported that microhardness of enamel remained the same after applying $10 \%$ carbamide peroxide. Results from our study are partially consistent to the study of Basting et al. who reported a significant reduction of enamel microhardness after application of $10 \%$ carbamide peroxide but also upturn of the value after remineralization period of 7 days [22]. The reason for inconsistent results could be the fact that in their study the treatment lasted much longer (42 days).

In the current study, the effect of $35 \%$ carbamide peroxide on microhardness of enamel was significantly reduced after completion of the treatment (after 3 hours). A significant reduction in microhardness after completion of the treatment can be explained by the fact that 35\% carbamide peroxide corresponds to $11.4 \%$ solution of hydrogen peroxide (the rest is urea) and it is still much higher concentration compared to $3 \%$ of hydrogen peroxide. Enamel microhardness values of the experimental samples returned to its original value after three weeks storage in artificial saliva. Since there was no significant difference between the control and the experimental samples and the values of microhardness returned after a period of remineralization it was an indication that enamel was completely "recovered". Reaching the initial values of microhardness can be explained by remineralization effect of the saliva. Our results are also consistent to the results of Attin et al. [11] and Lewinstein et al. [16], who showed a significant decrease in microhardness of enamel after the treatment with $35 \%$ carbamide peroxide. The results of the current study are partially in agreement with the results of Attin et al. [19] and Oltu et al. [26] since they reported a significant reduction of enamel microhardness after the treatment completion which was not returned to the initial level after the period of remineralization. Their findings were explained by the fact that the samples were kept briefly in artificial saliva (5 days) after the treatment completion.

Inconsistent data obtained from different studies regarding the effect of bleaching agents on enamel microhardness is the consequence of different methodologies used in research. This is especially true for the study of Attin et al. [19], who used enamel from bovine teeth. It is known that bovine enamel has three times faster progression of the lesions compared to human enamel. Oltu et al. [26] also showed a significant decrease of enamel microhardness value after exposure to $35 \%$ carbamide peroxide which did not reach the initial level after expected period of remineralization. Given that previous studies reported the contradictory data regarding the effect of different concentrations of carbamide peroxide on the mechanical properties of enamel, further research is required.

\section{CONCLUSION}

Based on the results from the current study it can be concluded that carbamide peroxide in the concentration of $10 \%$ does not affect the microhardness of enamel, while the concentration of $35 \%$ significantly reduces the enamel microhardness.

\section{REFERENCES}

1. Haywood VB, Heymann HO. Nightguard vital bleaching. Quintessence Int. 1989; 20:173-6.

2. Goldstein R, Garber D. Complete Dental Bleaching. Chicago, Berlin, London: Quintessence Publishing Co, Inc. 1995.

3. Cimili $\mathrm{H}$, Pameijer $\mathrm{CH}$. Effect of carbamide peroxide bleaching agents on the physical properties and chemical composition of enamel. Am J Dent. 2001; 14:63-6.

4. Rotstein I, Dankner E, Goldman A, Heling I, Stabholz A, Zalkind M. Histochemical analysis of dental hard tissues following bleaching. J Endod. 1996; 22:23-5.

5. Murchison DR, Charlton DG, Moore BK. Carbamide perokside bleaching: effects on enamel surface hardness and bonding. Oper Dent. 1992; 17:181-5.

6. Nathoo SA, Chmielewski MB, Kirkur RE. Effects of Colgate Platinum professional tooth whitening system on microhardness of enamel, dentin and composite resins. Compendium. 1994; 15:627-30.

7. Seghi RR, Denry I. Effect of external bleaching on indentation and abrasion characteristics of human enamel in vitro. J Dent Res. 1992; 71:140-4.

8. Unlu N, Cobankara FK, Altinoz C, Ozer F. Effect of home bleaching agents on the microhardness of human enamel and dentin. J Oral Rehabil. 2004; 1:57-61.

9. Ferreira IS, Lopes GC, Vieira LC, Araujo E. Effect of hyrdogen-peroxide-based home bleaching agents on enamel hardness. Braz J Oral Sci. 2006; 18:1090-3.

10. Leonard RH Jr, Eagle JC, Garland GE, Matthews KP, Rudd AL, Phillips C. Nightquard vital bleaching and its effect on enamel surface morphology. J Esthet Restor Dent. 2001; 13:132-9

11. Attin T, Kielbassa AM, Scwanenberg M, Heling E. Effect of fluoride treatment on remineralisation of bleached enamel. J Oral Rehabil. 1997; 24:282-6.

12. Basting RT, Rodrigues AL, Serra MC. The effect of $10 \%$ carbamide peroxide, carbopol and/or glycerin on enamel and dentin microhardness. Oper Dent. 2005; 30:608-16.

13. Araujo EM, Baratieri LN, Vieira LCC, Ritter AV. In situ effect of $10 \%$ carbamide peroxide on microhardness of human enamel: function of time. J Esthet Restor Dent. 2003; 15:166-74.

14. Smidt A, Weller D, Roman I, Gedalia I. Effect of bleaching agents on microhardness and surface morphology of tooth enamel. Am J Dent. 1998; 11:83-5.

15. Sulieman M, Addy M, Macdonald E, Rees JS. A safety study in vitro for the effects of an in-office bleaching system on the integrity of enamel and dentine. J Dent. 2004; 32:581-90.

16. Lewinstein I, Fuhrer N, Churaru N, Cardash H. Effect of different peroxide bleaching regimens and subsequent fluoridation on the hardness of human enamel and dentin. J Prosthet Dent. 2004; 92:337-42.

17. Pinto CF, Oliveira R, Cavalli V, Giannini M. Peroxide bleaching agent effects on enamel surface microhardness, roughness and morphology. Br Oral Res. 2004; 18:306-11.

18. Pinheiro-Junior EC, Fidel RAS, da Cruz-Filho AM, Silva RG, Pecora JD. In vitro action of various carbamide peroxide gel bleaching agents on the microhardness of human enamel. Br Dent J. 1996; 7:75-9. 
19. Attin T, Muller T, Patyk A, Lennon AM. Influence of different bleaching systems on fracture toughness and hard ness of enamel. Oper Dent. 2004; 29:188-95.

20. De Oliveira R, Paes Leme AF, Giannini M. Effect of carbamide peroxide bleaching gel containing calcium or fluoride on human enamel surface microhardness. Br Dent J. 2005; 16:103-6.

21. http://en.wikipedia.org/wiki/Knoop_hardness_test

22. Basting RT, Rodrigues AL Jr, Serra MC. The effect of $10 \%$ carbamide peroxide bleaching material on micro-hardness of sound and demineralized enamel and dentin in situ. Oper Dent. 2001; 26:531-53.
23. McCracken MS, Haywood VB. Demineralization effects of 10 percent carbamide peroxide. J Dent. 1996; 24:395-8.

24. Frysh H, Bowles WH, Baker F, Rivera-Hidalgo G, Guillen G. Effect of $\mathrm{pH}$ on hydrogen peroxide bleaching agents. J Esthet Dent. 1995; 7(3):130-3.

25. Featherstone JD, Cutress TW, Rodgers BE, Dennison PJ. Remineralization of artificial caries-like lesion in vivo by a selfadministered mouthrinse or paste. Caries Res. 1982; 16:235-42.

26. Oltu U, Gurgan S. Effects of three concentrations of carbamide peroxide on structure of enamel. J Oral Rehabil. 2000; 27:332-40.

Received: 04/08/2010 • Accepted: 05/11/2010 


\title{
Uticaj preparata za izbeljivanje zuba na mikrotvrdoću gleđi
}

\author{
Tatjana Savić-Stanković, Branislav Karadžić \\ Klinika za bolesti zuba i endodonciju, Stomatološki fakultet, Univerzitet u Beogradu, Beograd, Srbija
}

\begin{abstract}
KRATAK SADRŽAJ
Uvod Sredstva koja se koriste za izbeljivanje zuba mogu da dovedu do promena na tvrdim zubnim tkivima. Cilj ovog rada je bio da se ispita efekat dve koncentracije (10\% i 35\%) karbamid-peroksida, sredstva za izbeljivanje zuba, na mikrotvrdoću gleđi.

Materijal i metode rada Istraživanje je obavljeno na 10 ekstrahovanih zuba podeljenih u dve grupe. Svi zubi su presečeni dijamantskim diskom u meziodistalnom pravcu, kako bi se dobili eksperimentalni i kontrolni uzorci. Prva grupa je izlagana koncentraciji od 10\% karbamid-peroksida (Opalescence gel, Ultradent. Pro, US) u vremenskim intervalima koji odgovaraju primeni tzv. kućno-noćne tehnike beljenja vitalnih zuba. Druga grupa je izlagana koncentraciji od 35\% karbamid-peroksida (Opalescence Quick, Ultradent. Pro, US) u vremenskim intervalima koji odgovaraju primeni ambulantne tehnike beljenja vitalnih zuba. Kontrolni uzorci su izlagani veštačkoj pljuvački u istim vremenskim intervalima kao i eksperimentalne polovine. Knopov (Knoop) test merenja mikrotvrdoće gleđi primenjen je na početku, posle prve faze terapije, na kraju terapije i posle tri nedelje izloženosti veštačkoj pljuvački. Rezultati su statistički obrađeni primenom analize varijanse (ANOVA) i Studentovog t-testa.

Rezultati Vrednosti mikrotvrdoće gleđi eksperimentalnih uzoraka tretiranih desetoprocentnim rastvorom karbamid-peroksida se smanjuju nakon osam sati ( $261 \mathrm{khn}$ ) i nakon tri nedelje tretmana ( $222 \mathrm{khn})$, a povećavaju posle tri nedelje izloženosti veštačkoj pljuvački (263 khn). Izmereno smanjenje vrednosti mikrotvrdoće za gleđ koja je tretirana ovom koncentracijom karbamid-peroksida nije bilo statistički značajno. Vrednosti mikrotvrdoće gleđi eksperimentalnih uzoraka tretiranih tridesetpetoprocentnim rastvorom karbamid-peroksida se smanjuju nakon jednog sata (235 khn) i tri sata (190 khn), a povećavaju posle tri nedelje izloženosti veštačkoj pljuvački (241 khn). Smanjenje vrednosti mikrotvrdoće za gleđ koja je tretirana ovom koncentracijom karbamid-peroksida bilo je statistički značajno i u okviru grupe eksperimentalnih uzoraka i u odnosu na kontrolne uzorke.

Zaključak Karbamid-peroksid u koncentraciji od 35\% dovodi do značajnog smanjenja mikrotvrdoće gleđi u odnosu na efekat desetoprocentnog rastvora karbamid-peroksida.
\end{abstract}

Ključne reči: karbamid-peroksid; beljenje zuba; mikrotvrdoća gleđi

\section{UVOD}

Boja ili belina zuba, kao svojevrsni indikator zdravlja, ujedno je i veoma važan faktor mladosti i lepote. U potrazi za što konzervativnijim, najmanje agresivnim i ekonomski prihvatljivim tretmanom, beljenje zuba je postalo jedna od važnih opcija u stomatološkoj praksi. Prvi opis tehnike izbeljivanja vitalnih zuba, koji su 1989. godine objavili Hejvud (Haywood) i Hejman (Heymann) [1], otvorio je novo poglavlje u pristupu tretmana diskolorisanih zuba. Danas se na tržištu uglavnom nalaze materijali za izbeljivanje zuba čiju aktivnu supstancu čini vodonikperoksid ili karbamid-peroksid. Karbamid-peroksid u koncentraciji od $10 \%$ do $22 \%$ osnovni je agens u primeni tzv. kućnonoćne tehnike izbeljivanja vitalnih zuba, dok se u koncentraciji od 35\% primenjuje za ambulantno izbeljivanje. Karbamid-peroksid se in situ razlaže na ureu, amonijak, ugljen-dioksid, vodu i vodonik-peroksid, koji je aktivna supstanca [2].

Sredstva za izbeljivanje zuba stvaraju i promene u hemijskofizičkoj i morfološkoj strukturi gleđi, pa se i to mora uzeti u obzir prilikom ovog terapijskog postupka. Istraživanja pokazuju da postoji bliska veza između promena na površini gleđi (promene mikrotvrdoće, strukturne promene površine) i koncentracije sredstava za izbeljivanje $[3,4]$.

Dosadašnja istraživanja uticaja karbamid-peroksida na gleđ tokom izbeljivanja zuba pokazuju značajne kontradiktornosti [58]. Rezultati ukazuju na to da su eventualne promene neznatne i da se vraćaju na prvobitni nivo nakon prestanka terapije, dok drugi nalazi govore suprotno. Fereira (Ferreira) i saradnici [9] su u svom istraživanju pokazali da kontakt gleđi sa gelom za izbeljivanje ( $\mathrm{pH} 5,5) \mathrm{u}$ kratkom vremenskom periodu (ne dužem od 30 minuta) ne dovodi do promena u mikrotvrdoći. S druge strane, istraživanja Rotštajna (Rotstein) i saradnika [4], Leonarda (Leonard) i saradnika [10], Atina (Attin) i saradnika [11] i drugih autora ukazuju na to da postoji značajno smanjenje mikrotvrdoće gleđi zuba i nakon perioda remineralizacije. Novija istraživanja Bastingove (Basting) i saradnika [12] takođe ukazuju na značajno smanjenje mikrotvrdoće gleđi nakon primene desetoprocentnog rastvora karbamid-peroksida u trajanju od osam sati dnevno tokom 42 dana. Ove vrednosti se posle perioda remineralizacije od sedam dana vraćaju na početni nivo. Istraživanja Arauha (Araujo) i saradnika [13] su ukazala na značajno smanjenje mikrotvrdoće gleđi nakon primene desetoprocentnog rastvora karbamid-peroksida u trajanju od jednog sata ili sedam sati dnevno tokom tri nedelje u oba slučaja. Šmit (Smidt) i saradnici [14] su pokazali da je smanjenje mikrotvrdoće gleđi manje nakon izlaganja zuba karbamid-peroksidu u koncentraciji od 10\% (šest sati dnevno tokom 16 dana) gelovima čiji je $\mathrm{pH}$ u opsegu od 4,3 do 5,5.

Efekat visokih koncentracija preparata na bazi karbamidperoksida (35\%) i vodonik-peroksida (30-38\%), koje se koriste u ambulantnim uslovima beljenja zuba (engl. power bleaching), takođe je proveravan u funkciji promene biomehaničkih osobina gleđi. Ove koncentracije se inače koriste ili kao zasebna tehnika, ili u kombinaciji sa kućno-noćnom tehnikom izbeljivanja. Koncentracija od 35\% karbamid-peroksida je najveća na tržištu, a odgovara koncentraciji od 11,4\% rastvora vodonikperoksida. U istraživanju Sulimana (Sulieman) i saradnika [15] nije nađena značajna promena mikrotvrdoće gleđi nakon primene tridesetpetoprocentnog rastvora karbamid-peroksida tokom 30 minuta. Istraživanja Atina i saradnika [11] i Levinštajna (Lewinstein) i saradnika [16] ukazuju na značajno smanjenje mikrotvrdoće gleđi nakon tretmana koncentracijom od 35\% 
vodonik-peroksida ili karbamid-peroksida, koja se potpuno vraća nakon tretmana sa $0,05 \%$ rastvora fluorida $[11,16]$. Postoji veliki broj studija koje ukazuju na različite vrednosti smanjenja mikrotvrdoće gleđi posle primene tridesetpetoprocentnog rastvora karbamid-peroksida [3, 17-20].

Cilj ovog rada je bio da se ispita efekat dve različite koncentracije preparata karbamid-peroksida na mikrotvrdoću gleđi zuba.

\section{MATERIJAL I METODE RADA}

U eksperimentu je korišćeno deset izniklih intaktnih nekarijesnih premolara i trećih molara izvađenih iz ortodontskih razloga. Zubi su svrstani u dve grupe od po pet zuba. Ekstrahovani zubi prve i druge grupe su, radi sprečavanja dehidratacije, posle vađenja potapani u destilovanu i dejonizovanu vodu na $37^{\circ} \mathrm{C}$. Potom su premešteni u ultrazvučno kupatilo i čišćeni tri puta po 15 minuta. Neposredno pre izvođenja eksperimenta čuvani su u veštačkoj pljuvački u vodenom kupatilu na temperaturi od $37^{\circ} \mathrm{C}$ 24 časa. Dijamantskim diskom i niskoturažnim motorom sa svakog zuba je uklonjen koren 2-3 mm apikalno od gleđno-cementne granice. Zubi su potom isečeni u meziodistalnom pravcu dijamantskim diskom (Gebr. Brasseler \& KOMET, Germany) i niskoturažnim motorom čime su dobijena dva dela od kojih je jedan bio eksperimentalni a drugi kontrolni. Svaki deo je zatim uložen u autopolimerizujući akrilat (Simgal-R, Galenika), u cilindrične plastične kalupe prečnika od $3 \mathrm{~cm}$, tako da je vestibularna strana (gleđ) bila slobodna. Spoljašnja površina zubne gleđi je poravnata vodeno-hlađenim diskovima (Minnesota Mining \& MFG.Co.3M) finoće od 180, 320 i $600 \mu \mathrm{m}$. Ovaj postupak je obezbedio paralelne površine od oko $9 \mathrm{~mm}^{2}$ za merenje mikrotvrdoće Knopovim (Knoop) testom. Za delove zuba prve grupe, koji su izlagani desetoprocentnom rastvoru karbamid-peroksida, pre početka tretmana napravljeno je deset pojedinačnih trejeva, kako bi se simulirala situacija u ustima. Trej je bio napravljen od fleksibilnog etil-vinil acetatnog polimera debljine 0,9 mm (Soft-Tray, Ultradent Product. Inc) za svaki zub pojedinačno u vakuum-formeru (Ultradent. Pro, US).

Eksperimentalni delovi zuba prve grupe izlagani su karbamid-peroksidu ( $\mathrm{pH}$ 6,5) u koncentraciji od 10\% (Opalescence gel, Ultradent. Pro, US) u intervalima koji odgovaraju kliničkoj primeni kućno-noćne tehnike izbeljivanja vitalnih zuba (preporuka proizvođača). Njihove odgovarajuće kontrolne polovine su u istim vremenskim intervalima izlagane veštačkoj pljuvački. Svi uzorci zuba su potapani u sredstvo i veštačku pljuvačku u trajanju od osam sati tokom tri nedelje, tako što je svaki deo prekriven trejem i postavljen u zatvorenu posudu s veštačkom pljuvačkom $(\mathrm{pH} 7,0)$ na $37^{\circ} \mathrm{C}$. Posle osam sati vađeni su iz posudica i ispirani destilovanom nejonizovanom vodom pet sekundi. Za vreme preostalih 16 sati (tokom dana) uzorci su potapani u zasebne zatvorene posude s veštačkom pljuvačkom ( $\mathrm{pH} 7,0)$ na $37^{\circ} \mathrm{C}$. Veštačka pljuvačka u kontejnerima je menjana svakog trećeg dana. Po završetku tretmana (21 dan) uzorci obe grupe su čuvani samo u veštačkoj pljuvački tri nedelje. Knopov test mikrotvrdoće i eksperimentalnih i kontrolnih uzoraka je primenjen na početku eksperimenta, nakon osam sati i posle tri nedelje tretmana, odnosno posle tri nedelje stajanja u veštačkoj pljuvački.

Eksperimentalni delovi zuba druge grupe tretirani su karbamid-peroksidom ( $\mathrm{pH} 6,0$ ) u koncentraciji od 35\% (Opalescence
Quick, Ultradent. Pro, US) u vremenskim intervalima koji odgovaraju kliničkoj primeni ambulantnog izbeljivanja vitalnih zuba, a kontrolne polovine $\mathrm{u}$ istim vremenskim intervalima izlagane su veštačkoj pljuvački. Svi uzorci su izlagani agensu i veštačkoj pljuvački tokom 60 minuta svaka dva dana (tri puta nedeljno). Preostalo vreme su skladišteni u posude s veštačkom pljuvačkom ( $\mathrm{pH} 7,0)$ na $37^{\circ} \mathrm{C}$. Knopovim testom je proveravana mikrotvrdoća: na početku, nakon 60 minuta tretmana, posle serije od tri puta po 60 minuta (kraj terapije) i posle tri nedelje stajanja u veštačkoj pljuvački.

Za sve uzorke obe grupe vršena su tri merenja u srednjoj trećini krunice zuba s opterećenjem na svakom delu zuba od $50 \mathrm{~g}$ 30 sekundi na aparatu Leitz Wetzlar 7569 (Germany). Za statističku obradu podataka primenjeni su analiza varijanse (ANOVA) i Studentov t-test za nezavisne uzorke.

\section{REZULTATI}

Srednja vrednost mikrotvrdoće eksperimentalnih uzoraka izlaganih desetoprocentnom rastvoru karbamid-peroksida na početku merenja bila je 273,08 khn, nakon osam sati 261,06 khn, da bi se posle tri nedelje tretmana smanjila na $222,15 \mathrm{khn}$, dok se posle perioda izlaganja veštačkoj pljuvački u trajanju od tri nedelje povećala na 262,53 khn (Tabela 1). Promene mikrotvrdoće eksperimentalnih uzoraka nisu bile statistički značajne $(\mathrm{F}=0,670 ; \mathrm{p}>0,05)$.

Srednje vrednosti mikrotvrdoće kontrolnih uzoraka bile su prilično ujednačene tokom eksperimenta. Razlike u vrednostima mikrotvrdoće između eksperimentalnih i kontrolnih uzoraka nisu bile statistički značajne $(\mathrm{F}=0,660 ; \mathrm{p}>0,05)$.

Srednja vrednost mikrotvrdoće eksperimentalnih uzoraka izlaganih tridesetpetoprocentnom rastvoru karbamid-peroksida na početku eksperimenta bila je 261,00 khn, nakon jednog sata izlaganja gelu smanjila se na $234,60 \mathrm{khn}$, a posle tri sata na 190,00 khn, da bi se posle tri nedelje stajanja u veštačkoj pljuvački povećala na $241,20 \mathrm{khn}$ (Tabela 2). Najveća razlika u vrednostima mikrotvrdoće uočena je između početnih i vrednosti posle tri sata tretmana $(t=5,139 ; \mathrm{p}<0,05)$.

Srednje vrednosti mikrotvrdoće kontrolnih uzoraka su i ovde bile približno istih vrednosti tokom trajanja eksperimenta. Razlike u vrednostima mikrotvrdoće eksperimentalnih i kontrolnih uzoraka posle tretmana karbamid-peroksidom $\mathrm{u}$ koncentraciji od $35 \%$ bile su statistički značajne $(\mathrm{F}=4,434 ; \mathrm{p}<0,05)$.

Razlike u vrednostima mikrotvrdoće eksperimentalnih i kontrolnih uzoraka nakon perioda remineralizacije nisu bile statistički značajne.

\section{DISKUSIJA}

Tvrdoća čvrstih supstanci može se odrediti statičkim, dinamičkim i specijalnim metodama. Statičke metode po Knopu i Vikersu (Vickers) koriste se za merenje mikrotvrdoće čvrstih zubnih tkiva, a sila ispitivanja koja deluje na utiskivač postepeno se povećava do maksimalne vrednosti [21]. Knopov test tvrdoće je usvojen kao jedan od osnovnih eksperimentalnih metoda za analizu fizičkih promena gleđi i dentina nakon dejstva različitih agensa, što je bio i glavni razlog da se primeni u ovom istraživanju $[3,5,6]$. 
Najvalidniji rezultati fizičkih promena gleđi pod dejstvom različitih agensa za izbeljivanje mogu se dobiti istraživanjem $u$ uslovima in vivo. Puferski potencijal pljuvačke se ne može zanemariti, a pogotovo ne njen remineralizacioni efekat. Sastav pljuvačke se često menja u toku samo jednog dana, što znatno otežava simulaciju fizioloških uslova u eksperimentalnoj sredini [11].

Tokom procesa izbeljivanja zuba vodonik-peroksid difunduje kroz organski matriks gleđi. Vodonik-peroksid je oksidacioni agens i ima sposobnost da proizvodi slobodne radikale perhidroksilni i superoksidni jon, koji su veoma reaktivni. Iako je izbeljivanje zuba složen proces, glavna reakcija je reakcija oksidacije [22]. Tokom ovog procesa dolazi do molekularnih promena u okviru organske strukture tvrdih zubnih tkiva [4]. Kao posledica oksidacije organskog i neorganskog sastava gleđi rastvara se gleđni matriks i javljaju se sporedni efekti. Oni se ogledaju u promeni mikrotvrdoće gleđi i njenih morfoloških osobina [23]. Efekat izbeljivanja direktno zavisi od vremena izlaganja sredstvu za beljenje i njegove koncentracije. Što je duži period izlaganja i koncentracija sredstva za izbeljivanje veća, to je promena boje izrazitija, ali je i proces oksidacije duži, pa tako i njegov efekat na tvrda zubna tkiva $[19,20,21]$. Dejstvo materijala za izbeljivanje (u smislu pojave sporednih efekata) takođe zavisi od $\mathrm{pH}$ vrednosti sredstva za beljenje, ali i od kvaliteta tvrdih zubnih tkiva [24].

Rezultati ovog istraživanja su pokazali promene u mikrotvrdoći tretirane gleđi nakon primene veće koncentracije karbamid-peroksida. Uočene razlike u vrednostima mikrotvrdoće gleđi verovatno su posledica različitih koncentracija agensa za izbeljivanje, odnosno trajanja njihove primene, budući da su opterećenje (sila), prečnik dijamantnog utiskivača i vreme utiskivanja bili strogo kontrolisani i standardizovani. Osim toga, preparati koji su korišćeni u ovom istraživanju imaju pH vrednosti koje su iznad kritičnih za demineralizaciju gleđi. Rezultati su takođe pokazali da nije došlo do statistički značajnog smanjenja mikrotvrdoće posle primene desetoprocentnog rastvora karbamid-peroksida. Ovo se može objasniti činjenicom da je reč o veoma niskoj koncentraciji karbamid-peroksida, koja se u kontaktu s pljuvačkom i tečnostima u ustima razlaže na sedmoprocentnu ureu i troprocentni vodonik-peroksid, a dalje na vodu i slobodni nascentni kiseonik [1]. Posle čuvanja uzoraka u veštačkoj pljuvački mikrotvrdoća gleđi se povećala, što se dovodi u vezu s remineralizacionim dejstvom pljuvačke [25].

Dobijeni nalazi su u skladu s rezultatima istraživanja Marčisona (Murchison) i saradnika [5], Natoa (Nathoo) i saradnika [6], Senjija (Seghi) i Denrija (Denry) [7] i Unlua (Unlu) i saradnika [8], koji takođe nisu uočili promene mikrotvrdoće gleđi nakon primene desetoprocentnog rastvora karbamid-peroksida. Ovi rezultati su delimično u skladu i sa istraživanjem Bastingove (Basting) i saradnika [22], koji su ustanovili značajno smanjenje mikrotvrdoće gleđi posle primene ove koncentracije karbamid-peroksida, ali i vraćanje ovih vrednosti posle remineralizacije od samo sedam dana. Razlog za ove razlike u rezultatima mogao bi da leži u činjenici da je tretman trajao znatno duže - 42 dana.

Analiza dejstva karbamid-peroksida u koncentraciji od 35\% na mikrotvrdoću gleđi u ovom istraživanju ukazuje na njeno značajno smanjenje po završetku tretmana (posle tri sata). Ovo smanjenje se može objasniti činjenicom da karbamid-peroksid u ovoj koncentraciji odgovara rastvoru vodonik-peroksida od $11,4 \%$ (ostatak čini urea), što je ipak viša koncentracija vodonik-peroksida u odnosu na troprocentni rastvor. Vrednosti mikrotvrdoće gleđi eksperimentalnih uzoraka su se posle tri nedelje stajanja u veštačkoj pljuvački vratile na početne. S obzirom na to da nije zabeležena značajna razlika između kontrolnih i eksperimentalnih uzoraka, te da su se vrednosti mikrotvrdoće gleđi nakon perioda remineralizacije vratile na početne, može se reći da se gleđ potpuno „oporavila“. Dostizanje vrednosti mikrotvrdoća do početnog nivoa može se objasniti remineralizacionim efektom pljuvačke. Dobijeni nalazi su u skladu s rezultatima istraživanja Atina i saradnika [11] i Levinštajna i saradnika [16], a delimično i u saglasnosti s rezultatima druge studije Atina [19] i istraživanja Oltua (Oltu) i saradnika [26], koji su uočili značajno smanjenje mikrotvrdoće gleđi nakon prestanka tretmana, koja se nakon perioda očekivane remineralizacije nije vratila na početni nivo. Oni ovo tumače činjenicom da su uzorci po završetku tretmana kratko čuvani u veštačkoj pljuvački (pet dana).

Različiti podaci o promeni mikrotvrdoće gleđi posle primene sredstava za izbeljivanje dobijeni u drugim studijama posledica su primene različitih metodologija istraživanja. Ovo se posebno odnosi na studiju Atina i saradnika [19] koja je izvedena na goveđoj gleđi, za koju se zna da ima tri puta bržu progresiju lezija u odnosu na gleđ kod ljudi. Oltu i saradnici [26] su takođe ukazali na značajno smanjenje mikrotvrdoće posle dejstva karbamid-peroksida u koncentraciji od 35\%, koje, i posle perioda očekivane remineralizacije, nije dostigla početni nivo. $S$ obzirom na to da su nalazi dosadašnjih studija dejstva različitih koncentracija karbamid-peroksida na mehanička svojstva gleđi zuba oprečna, neophodna su dalja istraživanja u ovoj oblasti stomatologije.

\section{ZAKLJUČAK}

Na osnovu dobijenih rezultata može se zaključiti da karbamid-peroksid u koncentraciji od 10\% ne utiče na mikrotvrdoću gleđi, dok koncentracija od 35\% dovodi do njenog značajnog smanjenja. 